\title{
Symbiotic propagation of seedlings of Cyrtopodium glutiniferum Raddi (Orchidaceae)
}

\author{
Fernanda Aparecida Rodrigues Guimarães ${ }^{1}$, Marlon Corrêa Pereira ${ }^{2}$, Cristiane da Silva Felício ${ }^{1}$, \\ Denise Pereira Torres ${ }^{3}$, Sabrina Feliciano Oliveira ${ }^{4}$, Tomás Gomes Reis Veloso ${ }^{4}$ and Maria Catarina Megumi Kasuya ${ }^{4}$
}

Received: 3 November, 2012. Accepted: 19 July, 2013

\begin{abstract}
In nature, orchid seeds obtain the nutrients necessary for germination by degrading intracellular fungal structures formed after colonization of the embryo by mycorrhizal fungi. Protocols for asymbiotic germination of orchid seeds typically use media with high concentrations of soluble carbohydrate and minerals. However, when reintroduced into the field, seedlings obtained via asymbiotic germination have lower survival rates than do seedlings obtained via symbiotic germination. Tree fern fiber, the ideal substrate for orchid seedling acclimatization, is increasingly scarce. Here, we evaluated seed germination and protocorm development of Cyrtopodium glutiniferum Raddi cultivated in asymbiotic media (Knudson C and Murashige \& Skoog) and in oatmeal agar (OA) medium inoculated with the mycorrhizal fungus Epulorhiza sp., using non-inoculated OA medium as a control. We also evaluated the performance of tree fern fiber, pine bark, eucalyptus bark, corncob and sawdust as substrates for the acclimatization of symbiotically propagated plants. We determined germination percentages, protocorm development and growth indices at 35 and 70 days of cultivation. Relative growth rates and the effects of substrates on mycorrhizal formation were calculated after 165 days of cultivation. Germination efficiency and growth indices were best when inoculated OA medium was used. Corncob and pine bark showed the highest percentages of colonized system roots. The OA medium inoculated with Epulorhiza sp. shows potential for C. glutiniferum seedling production. Corncob and pine bark are promising substitutes for tree fern fiber as substrates for the acclimatization of orchid seedlings.
\end{abstract}

Key words: Epulorhiza sp., symbiosis, orchid, substrate, fern fiber

\section{Introduction}

Starch is the main source of carbon for immature orchid seeds. However, during the seed formation phase, starch is replaced by proteins, lipids and complex reserve sources, such as cellulose and hemicellulose (Rasmussen 1995). In some orchid species, large quantities of protein lead to seed dormancy (Hadley 1982). In addition, orchids produce seeds that are small and do not contain sufficient nutritional material for their initial development, characteristics that result in dependency on external carbon sources (McKendrick et al. 2002; Sequeira 2007) and in a low percentage of seeds germinating (Corrie \& Tando 1993). Therefore, in natural conditions, symbiotic association enables seed germination in orchids (Dearnaley 2007). Symbiotic fungi colonize the parenchyma cells near the suspensor of the embryo of the orchid seed (Peterson et al. 2004). The intracellular structures (pelotons) formed by the fungus within these cells are degraded by the embryo to obtain the nutrients required for its germination and development until the establishment of the adult plant, a phenomenon known as "mycoheterotrophy" (Rasmussen 1995; Peterson et al. 2004).

Various culture media have been developed for the asymbiotic in vitro germination of orchid seeds; that is, without the presence of the fungal symbiont (Rasmussem 1995; Martini et al. 2001). The use of different formulations of media, with the addition of mineral salts, hormones, vitamins or organic compounds, is aimed at improving the germination and the asymbiotic in vitro development of these seedlings (Martini et al. 2001; Campos 2004; Rodrigues et al. 2012). However, in vitro experiments have shown that symbiotic seed germination enables faster development than does germination in asymbiotic culture media (Markovina \& McGee 2000; Takahashi et al. 2001; Stewart \& Kane 2006).

\footnotetext{
${ }^{1}$ Universidade Federal de Viçosa, Departamento de Fitotecnia, Viçosa, MG, Brazil

${ }^{2}$ Universidade Federal de Viçosa, Instituto de Ciências Biológicas e da Saúde, Rio Paranaíba, MG, Brazil

${ }^{3}$ Universidade Federal de Viçosa, Departamento de Fitopatologia, Viçosa, MG, Brazil

${ }^{4}$ Universidade Federal de Viçosa, Departamento de Microbiologia, Viçosa, MG, Brazil

${ }^{5}$ Author for correspondence: marlon.pereira@ufv.br
} 
For the acclimatization of seedlings propagated in vitro, tree fern fiber, obtained by shredding the stem of Dicksonia sellowiana Hook, known locally as samambaiaçu, was once one of substrates most widely used by orchid enthusiasts and commercial orchid growers in Brazil. However, because there has been extensive extraction of these tree ferns and to require 15-18 years to reach the ideal stage for extraction (Lorenzi \& Souza 2001), they are now on the official list of endangered plant species in Brazil (Brasil 2009). Therefore, measures to restrict the use of tree fern fiber and its derivatives have been implemented and alternative substrates have been tested (Demattê \& Demattê 1996; Faria et al. 2001; Macedo et al. 2011).

There are high diversity of orchids in Brazil, exceeding 2,400 species (Barros et al. 2012), and approximately 39 species are endangered (Brasil 2009). Studies on the symbiotic propagation of seedlings are thus fundamental for programs of reintroduction of endangered species, as well as for the production of seedlings of orchids of commercial interest (Zettler 1997). Consequently, it is essential to select substrates other than tree fern fiber to acclimatization of Orchidaceae seedlings.

Cyrtopodium glutiniferum Raddi is a rupicolous orchid found in the Brazilian southeast, in the states of Minas Gerais and Rio de Janeiro (Bocayuva 2007; Barros et al. 2012). It flowers between July and November and usually fruits in this same period (Bocayuva 2007). It has great ornamental value because of the characteristics of its vegetative part and inflorescences (Caramaschi 2001). The species is also of medical importance, because its pseudobulbs contain a carbohydrate with anti-inflammatory properties (glucomannan) and other chemical compounds with potential applications (Barreto \& Parente 2006).

The main objective of this study was to compare the germination and development of seeds of C. glutiniferum cultivated in asymbiotic media with those cultivated in medium inoculated with the mycorrhizal fungus. We selected two asymbiotic media commonly used in orchid seed germination: Knudson C (KC, Knudson 1922); and Murashige \& Skoog (MS, Murashige \& Skoog 1962). To evaluate symbiotic germination, the mycorrhizal fungus Epulorhiza sp. was inoculated into oatmeal agar (OA) medium (Pereira et al. 2005). In addition, we evaluated the use of substrates other than tree fern fiber for the acclimatization of the symbiotically propagated seedlings.

\section{Material and methods}

The experiments were conducted in the Laboratory of Mycorrhizal Associations and in the greenhouse of the Department of Microbiology/Institute for Applied Agricultural Biotechnology, at the Federal University of Viçosa, located in the city of Viçosa, in the state of Minas Gerais, Brazil.

Mature capsules of C. glutiniferum were collected from adult individuals cultivated in greenhouses on the Barreto
2 farm, located in the Riograndina district of the municipality of Nova Friburgo, in the state of Rio de Janeiro. In the laboratory, the capsules were opened and $200 \mathrm{mg}$ of seeds were weighed using a precision scale (MARK 500; BEL Engineering, Monza, Italy). The seeds were superficially disinfected with a solution of $\mathrm{NaOCl}(2 \%$ of active $\mathrm{Cl})$ for $5 \mathrm{~min}$ and washed three times with autoclaved distilled water. The disinfected seeds were immersed in $50 \mathrm{~mL}$ of autoclaved distilled water under constant agitation. Later, with the aid of autoclaved micropipettes and tips, $200 \mu \mathrm{l}$ of the seed suspension (mean of 100 seeds per $200 \mu \mathrm{l}$ ) were pipetted into ten Petri dishes containing $25 \mathrm{~mL}$ of the OA culture medium (oatmeal $4 \mathrm{~g} \mathrm{~L}^{-1}$, agar $7.5 \mathrm{~g} \mathrm{~L}^{-1}$, distilled water, $\mathrm{pH}$ 5.6), five Petri dishes containing $\mathrm{KC}$ medium (sucrose $20 \mathrm{~g} \mathrm{~L}^{-1}$, $\mathrm{Ca}\left[\mathrm{NO}_{3}\right]_{2} 4 \mathrm{H}_{2} \mathrm{O} 1.000 \mathrm{~g} \mathrm{~L}^{-1}, \mathrm{KH}_{2} \mathrm{PO}_{4} 0.250 \mathrm{~g} \mathrm{~L}^{-1}, \mathrm{MgSO}_{4}$ $7 \mathrm{H}_{2} \mathrm{O} 0.250 \mathrm{~g} \mathrm{~L}^{-1},\left[\mathrm{NH}_{4}\right] \mathrm{SO}_{4} 0.5 \mathrm{~g} \mathrm{~L}^{-1}, \mathrm{FeSO}_{4} 7 \mathrm{H}_{2} \mathrm{O} 0.025 \mathrm{~g} \mathrm{~L}^{-1}$, $\mathrm{MnSO}_{4} 4 \mathrm{H}_{2} \mathrm{O} 0.007 \mathrm{~g} \mathrm{~L}^{-1}, 7.500 \mathrm{~g} \mathrm{~L}^{-1}, \mathrm{pH}$ 5.6) and five Petri dishes containing MS medium (MS Sigma salts $4.3 \mathrm{~g} \mathrm{~L}^{-1}$, agar $5.5 \mathrm{~g} \mathrm{~L}^{-1}$, sucrose $30 \mathrm{~g} \mathrm{~L}^{-1}$, $\mathrm{pH}$ 5.6).

Symbiotic germination was evaluated in the OA medium with the inoculation of the mycorrhizal fungus Epulorhiza sp., a natural symbiont of Epidendrum secundum Lindl. (Pereira et al. 2009). A disk $8 \mathrm{~mm}$ in diameter, containing fungal mycelium obtained from the borders of colonies of the fungus Epulorhiza sp. grown on potato dextrose agar medium (Merck, Darmstadt, Germany), was deposited in each of the Petri dishes containing OA medium and orchid seeds. The OA medium is frequently used to promote symbiotic germination, because it is a source of complex carbohydrates, which favor symbiosis. Dishes containing OA medium without inoculation of the mycorrhizal fungus were maintained as controls. Asymbiotic germination was evaluated in the KC and MS media. The dishes were sealed with PVC film and kept in a growth chamber at $28^{\circ} \mathrm{C}$, on a $16 / 8 \mathrm{~h} \mathrm{light/dark} \mathrm{cycle}$ (light at $38.20 \pm 10.42 \mu \mathrm{mol}$ photons $\mathrm{m}^{2} \mathrm{~s}^{-1}$ ).

The germination of seeds and the development of protocorms were evaluated at 35 and 70 days of incubation, with a stereoscopic light microscope (SZ40; Olympus, Tokyo, Japan). We considered six development stages, based on a modification of the methodology of Zettler \& Hofer (1998), as the following: $0=$ no germination; $1=$ well developed embryo inside the seed coat; 2 = rupture of the integument; 3 =formation of the promeristem; $4=$ formation of the first leaf with well-developed radicles; and $5=$ protocorm $0.5 \mathrm{~cm}$ in diameter, with formation of the second leaf and first roots.

At 35 and 70 days after sowing, we evaluated the number of protocorms in the different germination stages in the five applications of each treatment. These data were used to calculate the percentage of protocorms in the different development stages and the growth index of the protocorms. In this calculation, we considered the percentages of the protocorms classified as stages 2 through 5, because the absorption of water by the embryo might lead to responses similar to those described for stage 1 . The growth index of 
the protocorms was calculated using the following formula (Otero et al. 2005):

$$
\begin{aligned}
G I= & (N 1+N 2 \times 2+N 3 \times 3+N 4 \times 4+N 5 \times 5) \div \\
& (N 0+N 1+N 2+N 3+N 4+N 5)
\end{aligned}
$$

where GI is the growth index; and $N O$ is the number of seeds in stage $0, N 1$ is the number of seeds in stage 1, etc.

Tree fern stem, pine bark, eucalyptus bark, corncob and sawdust were tested as substrates. The experimental design was completely randomized, using six substrates, and each condition was applied in quintuplicate. The eucalyptus bark, corncob and sawdust were boiled for $60 \mathrm{~min}$ and autoclaved twice at $121^{\circ} \mathrm{C}$ for $40 \mathrm{~min}$, with an interval of $24 \mathrm{~h}$ between each autoclaving cycle. The tree fern fiber stem and the pine bark were used as commercially obtained. The substrates were transferred to $300 \mathrm{~mL}$ plant cell culture vessels (Magenta ${ }^{\mathrm{TM}}$; Sigma-Aldrich, St. Louis, MO, USA) and autoclaved at $121^{\circ} \mathrm{C}$ for $40 \mathrm{~min}$. Before transferring the plants to the substrates, we evaluated the total fresh weight of the plant, the length of the longest root, and the height of the shoot. One plant was placed in each culture vessel, five per substrate, and the vessels were filled to their maximum capacity with substrate.

The seedlings were kept in a greenhouse with $50 \%$ shading, watered once a week and fertilized every fifteen days with Clark's nutrient solution (Clark 1975). After 165 days, we repeated the evaluation of the total fresh weight of the plant, the length of the longest root, and the height of the shoot. These measures were used to calculate the relative growth rate (RGR) for each variable, using the following formula:

$$
R G R=\left(\ln E_{2}-\ln E_{1}\right) /\left(t_{2}-t_{1}\right)
$$

where $R G R$ is the relative growth rate; $\ln$ is the natural logarithm; $E_{1}$ and $E_{2}$ are the values of the variables obtained at the first and second evaluations, respectively; and $t_{1}$ and $t_{2}$, respectively, are the time, in days, of each evaluation.
To determine the effect of the substrates on the mycorrhization, we randomly selected three plants on each substrate and one root of each plant, evaluating three roots per substrate, after 165 days of cultivation. The roots were washed and sectioned into three equal fragments. From each fragment, we prepared 25 cross-sections. The percentage of mycorrhizal sections, the percentage of cortex colonization and the percentage of sections with intact and degraded pelotons were determined under light microscopy.

The data were submitted to one-way ANOVA with the F-test and the comparison of means was performed with Tukey's test at the 5\% level of significance, using the program Sisvar (Ferreira 2011). Graphs were generated by the program Sigma Plot, version 12.0 (Systat Software, San Jose, CA USA).

\section{Results and discussion}

The seeds of C. glutiniferum germinated in both asymbiotic media (KC and MS) and in the inoculated OA medium (Fig. 1). The seeds incubated in OA medium without inoculation did not germinate, remaining at stage 0 until the evaluation at 70 days. After 35 days of incubation, we observed protocorms at stage 3 in the inoculated $\mathrm{OA}$ medium and in the $\mathrm{KC}$ medium, whereas those in the MS medium the protocorms did not develop beyond stage 1 (Fig. 1A). At 70 days, we observed protocorms at stage 5 in the inoculated OA medium, whereas the protocorms in the KC and MS media developed only to stage 3 (Fig. 1B). This indicates that the OA medium inoculated with Epulorhiza sp. was more efficient in promoting the germination and in vitro development of C. glutiniferum than were the asymbiotic media tested. During a periodic evaluation in experiments comparing symbiotic and asymbiotic methods, more advanced development is typically observed in symbiotic germination (Muir 1989; Markovina \& Mcgee, 2000; Takahashi et al. 2001; Nontachaiyapoom

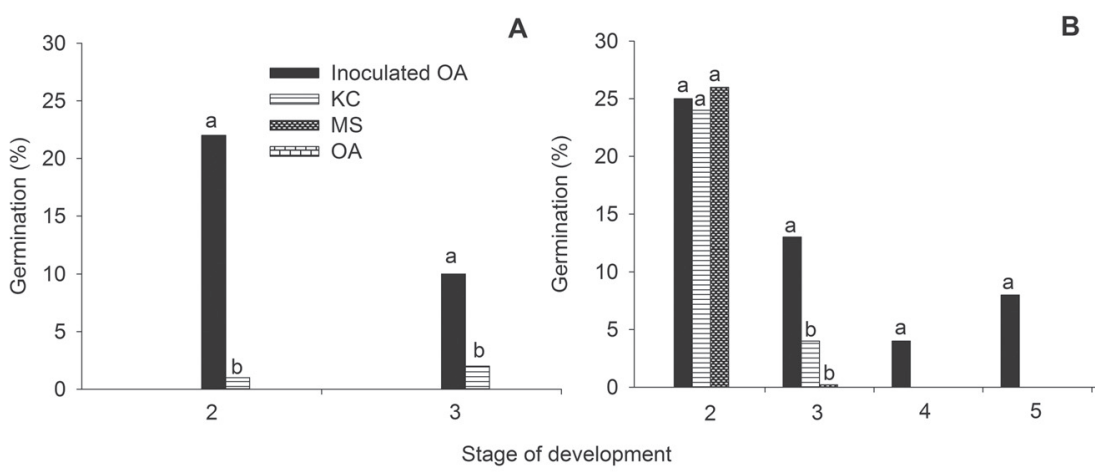

Figure 1. Percentage of seed germination and different development stages of the protocorms of Cyrtopodium glutiniferum Raddi at 35 and 70 days of incubation (A and B, respectively) in the asymbiotic media-Murashige \& Skoog (MS) and Knudson C (KC) - and in the symbiotic media-oatmeal agar medium (OA) with and without inoculation of the mycorrhizal fungus Epulorhiza sp. Means followed by the same letter in each development stage indicate no statistically significant difference, according to Tukey's test at a probability of $5 \%$. 
et al. 2011). Considering that the OA medium used in the symbiotic method is nutrient poor, the faster development of protocorms in this medium indicates the importance of mycorrhizal fungi on the germination and development of orchids. However, Nontachaiyapoom et al. (2011) obtained protocorms of Dendrobium draconis Rchb. f. with a well-developed first leaf (stage 5) at similar percentages between the seeds germinated with the symbiotic method (OA medium inoculated with the fungus Epulorhiza sp.) and the seeds germinated with the asymbiotic method (MS medium). According to the authors, the metabolism of the seeds of this plant might be more adapted to respond to an exogenous carbon source than that of other orchids. Simple sugars, such as sucrose, may serve as an exogenous source of carbon and energy for the development of the orchid embryo, from the heterotrophic phase of protocorm until reaching the autotrophic phase of juvenile or adult plant (Rasmussen 1995; Nontachaiyapoom et al. 2011). Therefore, asymbiotic media are rich in sugar.

Asymbiotic media are routinely used for seed germination of orchids in the commercial production of seedlings (Campos 2004). Several studies invested in asymbiotic media to germinate the seeds of terrestrial and epiphyte endangered species of orchids (Zeng et al. 2012; Roy et al. 2011). In some studies, the obtained seedlings were reintroduced to their natural habitats with a survival rate reaching $60 \%$ of the seedlings after two years in the field (Zeng et al. 2012).

The incapacity of the seeds to germinate in the OA medium without the inoculation of the mycorrhizal fungus confirms the necessity of the seed to associate with a compatible fungus from which to obtain simple carbon molecules, such as trioses and hexoses. This association is necessary because the lipid and protein reserves of the embryo are not sufficient to enable the beginning of its development (Peterson et al. 2004). However, the efficiency of such association might vary for fungal isolates of a same species, same genus or different genera (Otero et al. 2005). Some orchid species germinate only in the presence of their fungal symbiont (Pereira et al. 2005). Others might germinate in association with fungi obtained from other orchid species (Zettler 1997). Fungal isolates obtained from the same orchid and morphologically equal might have different percentages of germination and development of protocorms when co-inoculated with seeds of their host plant (Pereira et al. 2011). This suggests that there is no absolute specificity between the orchid and the fungal symbiont in vitro. Therefore, for the utilization of mycorrhizal fungi on the symbiotic production of seedlings, it is important to test the efficiency of the fungus in promoting the germination and development of seedlings (Rasmussen 2002; Stewart \& Kane 2006). The isolate of Epulorhiza sp. used in this study was the one with the highest growth index in the experiment performed by Pereira et al. (2011). It has also been successfully used in the seed germination of other orchid species (unpublished data) and has been considered a promising isolate for the production of orchid seedlings.

The inoculation promoted the highest growth index of the protocorms, approximately 1.0 at 35 days, whereas the other culture media had an index below 0.2 (Fig. 2A) and can be considered of low efficiency, according to the results obtained by Pereira et al. (2011). At 70 days the inoculated medium was also the one with the highest growth rate, approximately 1.8 , whereas the other culture media had as index of approximately 1.0 (Fig. 2B). The inoculation of the mycorrhizal fungus was fundamental, because it enabled the development of the protocorms in a short period of time, in comparison to the asymbiotic media. Additionally, it reduced the production costs, considering that the OA medium is relatively inexpensive in comparison to the commercial asymbiotic media.

The relative growth rates for the variables analyzed did not differ by the Tukey's test ( $\mathrm{p}>0.05)$ for the substrates studied, despite the occurrence of discrepancies (Tab. 1). However, alternative substrates to tree fern fiber such as pine bark, eucalyptus bark, coconut shell chips, coconut fiber, mixed with peat and perlite, have been efficient for
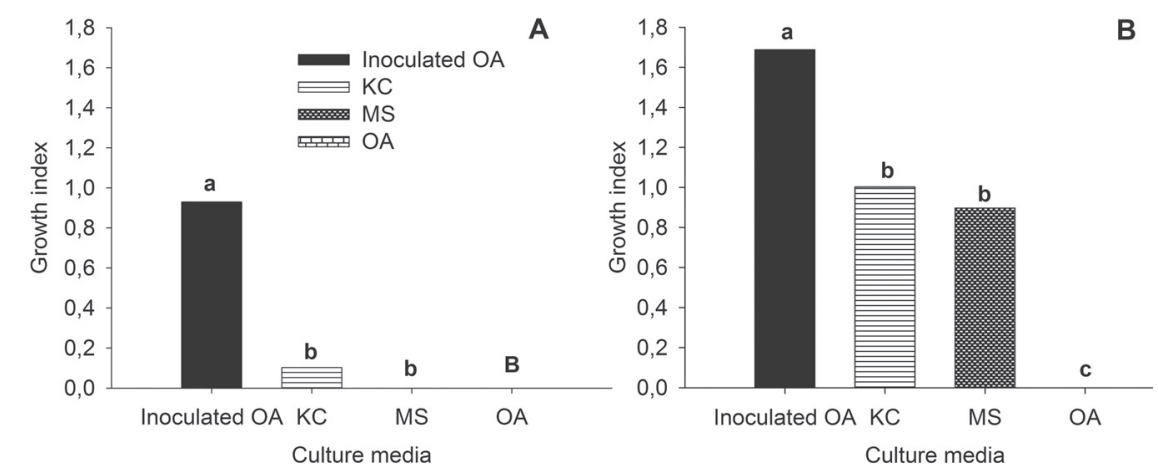

Figure 2. Growth index of the protocorms of Cyrtopodium glutiniferum Raddi at 35 and 70 days of incubation (A and B, respectively) in the asymbiotic media-Murashige \& Skoog (MS) and Knudson C (KC) - and in the symbiotic media-oatmeal agar medium (OA) with and without inoculation of the mycorrhizal fungus Epulorhiza sp. Means followed by the same letter indicate no statistically significant difference, according to Tukey's test at a probability of $5 \%$. 
Fernanda Aparecida Rodrigues Guimarães, Marlon Corrêa Pereira, Cristiane da Silva Felício,

Denise Pereira Torres, Sabrina Feliciano Oliveira, Tomás Gomes Reis Veloso and Maria Catarina Megumi Kasuya

Table 1. Relative growth rates for the variables fresh weight, length of the longest root and height of the shoot of seedlings of Cyrtopodium glutiniferum Raddi after 165 days of cultivation on different substrates.

\begin{tabular}{lccc}
\hline Substrate & $\begin{array}{c}\text { Fresh weight } \\
\left(\mathrm{mg} \mathrm{day}^{-1}\right)\end{array}$ & $\begin{array}{c}\text { Longest root, length } \\
\left(\mathrm{mm} \mathrm{day}^{-1}\right)\end{array}$ & $\begin{array}{c}\text { Shoot height } \\
\left(\mathrm{mm} \mathrm{day}^{-1}\right)\end{array}$ \\
\hline Eucalyptus bark & $14.59 \mathrm{a}$ & $0.087 \mathrm{a}$ & $0.059 \mathrm{a}$ \\
Corncob & $17.57 \mathrm{a}$ & $0.078 \mathrm{a}$ & $0.083 \mathrm{a}$ \\
Pine bark & $21.78 \mathrm{a}$ & $0.087 \mathrm{a}$ & $0.087 \mathrm{a}$ \\
Sawdust & $15.97 \mathrm{a}$ & $0.107 \mathrm{a}$ & $0.063 \mathrm{a}$ \\
Tree fern fiber & $22.04 \mathrm{a}$ & $0.093 \mathrm{a}$ & $0.102 \mathrm{a}$ \\
\hline
\end{tabular}

Means followed by the same letter in the same column indicate no statistically significant difference, according to Tukey's test at a probability of $5 \%$.

the cultivation of seedlings of orchids and other ornamental plants (Kanashiro et al. 2008). Coconut fiber and the pine bark-coconut fiber mix have been shown to be viable alternatives to tree fern fiber and peat moss for the cultivation of the orchid Cattleya intermedia Graham, during the period of acclimatization (Lone et al. 2008).

In the present study, although there was no difference between the substrates regarding growth $(\mathrm{p}>0.05)$, we observed that the values for weight and growth of the shoot obtained with pine bark were most similar to those obtained with tree fern fiber (Tab. 1). The pine bark in a mix with carbonized rice hull has also been shown to be efficient for the acclimatization of seedlings of the hybrid of the orchid C. intermedia X Hadrolaelia purpurata (Lindl. \& Paxton) Chiron \& V.P. Castro (Sorace et al. 2009).

Greater development of the roots in relation to the shoot was observed for the sawdust substrate (Tab. 1). According to Sequeira (2007), this development pattern can result from the hydric stress suffered by the seedlings. That author observed the same pattern in an evaluation of coconut shell chips as an alternative to tree fern fiber as a substrate for the growth of the orchid Hadrolaelia perrinii (Lindl.) Chiron \& V.P. Castro. In the remaining substrates, greater development of the shoot in relation to the roots was observed.

We observed that the type of substrate affected the mycorrhizal colonization of the roots of C. glutiniferum (Tab. 2). The percentage of mycorrhizal sections was highest for the substrates eucalyptus and corncob (Tab. 2), intermediate for sawdust and tree fern fiber and lowest for pine bark
(Tab. 2). The plants grown on pine bark and eucalyptus bark had the lowest values for colonization of the cortex, which did not differ significantly between the two (Tab. 2). The proportion of the cortex that was colonized was over $50 \%$ for the remaining substrates (Tab. 2). Substrates used in the acclimatization of mycorrhizal orchid seedlings must guarantee sufficient colonization of the roots in order to maintain the association throughout the development of the plant, thus increasing the expected seedling survival rate. The eucalyptus bark and corncob substrates had the highest percentages of colonized sections. Corncob had the highest percentage of cortex colonized and the second highest percentage of intact pelotons (Tab. 2).

In the present study, we found intact pelotons together with digested pelotons, which indicates the cyclical character of the association (Uetake et al. 1997; Sequeira 2007). Therefore, the period during which the plant actually benefits from the fungal association remains unknown, as does the appropriate timing of observation. Similar results were obtained by Sequeira (2007). According to Zettler et al. (1999), at an initial moment, the seeds would benefit from the association with mycorrhizal fungi, however there is a lack of studies that are sufficiently long to observe whether the future requirements of the plants are met by this association (Sequeira 2007).

As can be seen in Tab. 2, there were no difference between the substrates regarding the proportions of intact and degraded pelotons $(p>0.05)$. Substrates on which the percentages of degraded pelotons are higher are those on

Table 2. Percentages of mycorrhizal sections, colonized cortex, intact pelotons and degraded pelotons in the roots of Cyrtopodium glutiniferum Raddi after 165 days of cultivation on different substrates.

\begin{tabular}{lccc}
\hline Substrate & $\begin{array}{c}\text { Mycorrhizal sections } \\
(\%)\end{array}$ & $\begin{array}{c}\text { Colonized cortex } \\
(\%)\end{array}$ & \multicolumn{2}{c}{$\begin{array}{c}\text { Intact pelotons } \\
(\%)\end{array}$} & $26.70 \mathrm{a}$ \\
\hline Eucalyptus bark & $100.00 \mathrm{a}$ & $5.00 \mathrm{~b}$ & $73.30 \mathrm{a}$ \\
Corncob & $100.00 \mathrm{a}$ & $95.00 \mathrm{a}$ & $22.3 \mathrm{a}$ \\
Pine bark & $72.00 \mathrm{~b}$ & $24.13 \mathrm{~b}$ & $79.00 \mathrm{a}$ \\
Sawdust & $93.30 \mathrm{ab}$ & $65.41 \mathrm{a}$ & $50.20 \mathrm{a}$ \\
Tree fern fiber & $72.70 \mathrm{ab}$ & $83.74 \mathrm{a}$ & $32.00 \mathrm{a}$ \\
\hline
\end{tabular}

Means followed by the same letter in the same column indicate no statistically significant difference, according to Tukey's test at a probability of $5 \%$. 
which the plant gains the most benefit from the lysis of fungal structures (Uetake et al. 1997), because the minerals required for orchid development, such as phosphorus and nitrogen, are obtained during the degradation of pelotons (Cameron 2006; 2007; Dearnaley 2007). In addition, the presence of intact pelotons only, regardless of their quantity and the substrate employed, might indicate late infection or recolonization of the radicle cortex by the mycorrhizal fungi (Sequeira 2007).

When the objective is the introduction of seedlings in the field, analyses of the effect of substrates on the mycorrhizal association are fundamental, because seedlings with mycorrhizae have a greater chance of survival than do those with no mycorrhizae and seedlings cultivated by asymbiotic processes rarely survive when transferred to their natural habitat (Clements et al. 1986; Andersen \& Rasmussen 1996; Pereira et al. 2011).

\section{Conclusions}

The symbiotic method is highly efficient in promoting the germination of seeds and the development of protocor$\mathrm{ms}$ of C. glutiniferum. Corncob and pine bark are promising substrates for the acclimatization of seedlings of $C$. glutiniferum inoculated with mycorrhizal fungus, because they ensure a higher percentage of colonized sections.

\section{Acknowledgments}

The authors thank the Minas Gerais Instituto Estadual de Florestas (IEF, State Forest Institute) for authorizing the collection of orchid roots within protected areas in the state of Minas Gerais. The authors are also grateful to Dr. R. W. Barreto and Dr. D. W. Barreto, for providing the mature capsules of $C$. glutiniferum. Financial support was provided by the Fundação de Amparo à Pesquisa do Estado de Minas Gerais (FAPEMIG, Foundation for the Support of Research in the State of Minas Gerais) and the Brazilian Conselho Nacional de Desenvolvimento Científico e Tecnológico (CNPq, National Council for Scientific and Technological Development).

\section{References}

Andersen, T.F. \& Rasmussen, H.N. 1996. The mycorrhizal species of Rhizoctonia. Pp. 379-390. In: SNEH, S.; NEATE, S. \& DIJST, G., eds. Rhizoctonia species: taxonomy, molecular biology, ecology, pathology, and disease control. Dordrecht. Kluwer Academic Publishers.

Barros, F.; Vinhos, F.; Rodrigues, V.T.; Barberena, F.F.V.A.; Fraga, C.N. \& Pessoa, E.M. 2012 Lista de Espécies da Flora do Brasil. Jardim Botânico do Rio de Janeiro. http://floradobrasil.jbrj.gov.br/2012/ FB000179.html (Acesso em 30/06/2012).

Brasil. Ministério do Meio Ambiente (MMA). 2009. Instrução Normativa $\mathrm{n}^{\circ} 6$, de 23 de setembro de 2008. Lista oficial das espécies da flora brasileira ameaçadas de extinção. Diário Oficial da República Federativa do Brasil, Brasília, DF 145(185): 75-83.
Barreto, D.W. \& Parente, J.P. 2006. Chemical properties and biological activity of a polysaccharide from Cyrtopodium cardiochilum. Carbohydrate Polymers 64: 287-291.

Bocayuva, M.F.; Forzza, R.C. 2007. Orchidaceae no Parque Natural Municipal da Prainha, RJ, Brasil. Acta Botanica Brasilica 21 (2): 383-400.

Cameron, D.D.; Leake, J.R.; Read, D.J. 2006. Mutualistic mycorrhiza in orchids: evidence from plant-fungus carbon and nitrogen transfers in the green-leaved terrestrial orchid Goodyera repens. New Phytologist 171: 405-416.

Cameron, D.D.; Johnson, I.; Leake, J.R.; Read, D.J. 2007. Mycorrhizal acquisition of inorganic phosphorus by the green-leaved terrestrial orchid Goodyera repens. Annals of Botany 99: 831-834.

Campos, D.M. 2004. Cultura in vitro simplificada. O Mundo das Orquídeas 36: 52-53.

Caramaschi, G.M.C.L. 2001. Propagação in vitro de Cyrtopodium spp. (Orchidaceae). Brasília, Universidade de Brasília.

Clark, R.B. 1975. Characterization of phosphatase of intact maize roots. Journal of Agricultural and Food Chemistry 23(3): 458-460.

Clements, M.A.; Muir, H. \& Cribb, P.J. 1986. A preliminary report on the symbiotic germination of European terrestrial orchids. Kew Bulletin 41: $437-445$.

Corrie, S. \& Tando, P. 1993. Propagation of Cymbidium giganteum Wall. through high frequency conversion of encapsulated protocorms under in vivo and in vitro conditions. India Journal of Experimental Biology 31: 61-64.

Dearnaley, J.D.W. 2007. Further advances in orchid mycorrhizal research. Mycorrhiza 17: 475 - 486.

Demattê, J.B.I. \& Demattê, M.E.S.P. 1996. Estudos hídricos com substratos vegetais para cultivo de orquídeas. Pesquisa Agropecuária Brasileira 31(1): 803-813.

Faria, R.T.; Rego, L.V.; Bernardi, A. \& Molinari, H. 2001. Performance of different genotypes of Brazilian orchid cultivation in alternatives substrates. Brazilian Archives of Biology and Technology 44(4): 337-342.

Ferreira, D.F. 2011, Sisvar: a computer statistical analysis system. Ciência e Agrotecnologia 35(6): 1039-1042.

Hadley, G. 1982. Orchid mycorrhiza. Pp. 84-118. In: Arditti J. (Ed), Orchid Biology - Reviews and Perspectives II. Ithaca, Cornell University Press.

Kanashiro, S.; Minami, K.; Jocys, T.; Dias, C.T.S. \& Tavares, A. R. 2008. Substratos alternativos ao xaxim na produção de bromélia ornamental. Pesquisa Agropecuária Brasileira 43(10): 1319-1324.

Knudson, L. 1922. Nonsymbiotic germination of orchid seeds. Botanical Gazette 73(1): 1-25.

Lone, A.B.; Barbosa, C.M.; Takahashi, L.S.A. \& Faria, R.T. 2008. Aclimatização de Cattleya (Orchidaceae) em substratos alternativos ao xaxim e ao esfagno. Acta Scientiarum. Agronomy 30(4): 465-469.

Lorenzi, H. \& Souza, H.M. 2001. Plantas ornamentais do Brasil. 3. ed. Nova Odessa: Plantarum.

Macedo, M.C.; Rosa, Y.B.C.J.; Scalon, S.P.Q.; Junior, E.J.R.; Vieira, M.C. \& Tatara, M.B. 2011. Substratos e intensidades de luz no cultivo de orquídea denfal. Horticultura brasileira 29(2): 168-173.

Markovina, A.L. \& McGee, P.A. 2000. Comparison of symbiotic and asymbiotic seed germination and plantlet development in Sarcochilus (Vandeae; Orchidaceae). Lindleyana 15: 68-72.

Martini, P.C.; Willadino, L.; Alves, G.D.; Donato, V.M.T.S. 2001. Propagação de orquídea Gongora quinquenervis por semeadura in vitro. Pesquisa Agropecuária Brasileira 36(10): 1319-1324.

McKendrick, S.L.; Leake, J.R.; Taylor, D.L. \& Read, D.J. 2002. Symbiotic germination and development of the myco-heterotrophic orchid Neottia nidus-avis in nature and its requirement for locally distributed Sebacina spp. New Phytologist 154: 233-247.

Muir, H.J. 1989. Germination and mycorrhizal fungus compatibility in European orchids. In: Pritchard, H.W., Modern methods in orchid conservation: The role of physiology, ecology and management. Cambrigde, Cambridge University Press.

Nontachaiyapoom, S.; Sasirat, S. \& Manoch, L. 2011. Symbiotic seed germination of Grammatophyllum speciosum Blume and Dendrobium draconis Rchb. f., native orchids of Thailand. Scientia Horticulturae 130: 303-308. 
Otero, J.T.; Bayman, P. \& Ackerman, J.D. 2005. Variation in mycorrhizal performance in the epiphytic orchid Tolumnia variegate in vitro: the potential for natural selection. Evolutionary Ecology 19: 29-43.

Pereira, O.L.; Kasuya, M.C.M.; Rollemberg, C.L. \& Borges, A.C. 2005. Inducao in vitro da germinação de sementes de Oncidium flexuosum (Orchidaceae) por fungos micorrizicos rizoctonioides. Revista Brasileira de Ciência do Solo 29: 199-206.

Pereira, M.C.; Kasuya, M.C.M.; Pereira, O.L.; Costa, M.D. \& Rocha, R.B. 2009. Diversidade de fungos micorrízicos Epulorhiza spp. isolados de Epidendrum secundum (Orchidaceae). Revista Brasileira de Ciência do Solo 33: 1187-1197.

Pereira, M.C.; Torres, D.P.; Guimaraes, F.A.R.; Pereira, O.L. \& Kasuya, M.C. 2011. Germinação de sementes e desenvolvimento de protocormos de Epidendrum secundum Jacq. (Orchidaceae) em associação com fungos micorrízicos do gênero Epulorhiza. Acta Botanica Brasilica 25(3): 534-541.

Peterson, R.L.; Massicotte, H.B. \& Melville, L.H. 2004. Mycorrhizas: anatomy and cell biology. NRC Research Press.

Rasmussen, H.N. 2002. Recent developments in the study of orchid mycorrhiza, Plant and Soil 244: 149-163.

Rasmussen, H.N. 1995. Terrestrial orchid: from seed to mycotrophic plant. Cambridge, Cambridge University Press.

Rodrigues, D.T.; Novais, R.F.; Alvarez, V.H.V.; Dias, J.M.M. \& Villani, E.M.A. 2012. Concentrações e composições químicas do meio nutritivo para o cultivo in vitro de orquídea. Revista Ceres 59(1): 1-8.

Roy, A.R.; Patel, R.S.; Patel, V.V.; Sajeev, S. \& Deka B. C. 2011. Asymbiotic seed germination, mass propagation and seedling development of Vanda coerulea Griff ex. Lindl. (Blue Vanda): An in vitro protocol for an endangered orchid. Scientia Horticulturae 128: 325-331.

Sequeira, L.G.C.C. 2007. Avaliação de diferentes substratos e da inoculação de fungos rizoctonióides no crescimento inicial de
Hadrolaelia perrinii. Dissertação de Mestrado em Agricultura Tropical e Subtropical área de concentração em Gestão de Recursos Agroambientais. Instituto Agronômico de Campinas, Campinas.

Sorace, M.; Faria, R.T.; Fonseca, I.C.B.; Yamamoto, L. Y. \& Sorace, M.A.F. 2009. Substratos alternativos ao xaxim no cultivo do híbrido Cattleya intermedia X Hadrolaelia purpurata (Orchidaceae). Semina: Ciências Agrárias 30(4): 771-778.

Stewart, S.S. \& Kane, M.E. 2006. Symbiotic seed germination of Habenaria macroceratitis (Orchidaceae), a rare Florida terrestrial orchid. Plant Cell Tissues and Organ Culture 86: 159-167.

Takahashi, K.; Ogiwara, L. \& Hakoda, N. 2001. Inoculation of Habenaria (Pecteilis) radiata whit two isolates of orchid mycorrhizal fungi: germination and growth response to separate simultaneous, and consecutive inoculation. Lindleyana 16: 102-108.

Uetake, Y. Farquhar, M.L. \& Peterson, R.L. 1997. Changes in microtubule arrays in symbiotic orchid protocorms during fungal colonization and senescence. New Phytologist 135: 701-709.

Zeng, S.; Wu, K.; Silva, J.A.T.; Zhang, J.; Chen, Z.; Xia, N. \& Duan, J. 2012. Asymbiotic seed germination, seedling development and reintroduction of Paphiopedilum wardii Sumerh., an endangered terrestrial orchid. Scientia Horticulturae 138: 198-209.

Zettler, L.W. 1997. Terrestrial orchid conservation by symbiotic seed germination: techniques and perspectives. Selbyana 18: 188-194.

Zettler, L.W. \& Hofer, C.J. 1998. Propagation of the little club-spur orchid (Platanthera clavellata) by symbiotic seed germination and its ecological implications. Environmental and Experimental Botany 39: 189-195.

Zettler, L.W.; Burkhead, J.C \& Marshall, J.A. 1999. Use of mycorrhizal fungus from Epidendrum conopseum to germinate seed of Encyclia tampensis in vitro. Lindleyana 14: 102-105. 